\title{
ANATOMIA FOLIAR DE HALÓFITAS E PSAMÓFILAS REPTANTES OCORRENTES na Restinga de Ipitangas, Saquarema, Rio de Janeiro, Brasil
}

\author{
Rosani do Carmo de Oliveira Arruda ${ }^{1}$, Natasha Sanfilippo Fontes Viglio ${ }^{1}$ \\ \& Ana Angélica Monteiro de Barros ${ }^{2}$
}

\begin{abstract}
Resumo
(Anatomia foliar de halófitas e psamófilas reptantes ocorrentes na Restinga de Ipitangas, Saquarema, Rio de Janeiro, Brasil) O presente trabalho aborda a anatomia foliar de Blutaparon portulacoides (A. St.-Hil.) Mears. (Amaranthaceae), Ipomoea pes-caprae (L.) R. Br. e I. imperati (Vahl) Griseb. (Convolvulaceae), Canavalia rosea (Sw.) DC. e Sophora tomentosa L. (Leguminosae), Sporobolus virginicus (L.) Kunth (Poaceae) e Miegia maritima (Aubl.) Willd. (Cyperaceae). A maioria das espécies investigadas tem folhas suculentas e epiderme uniestratificada coberta por espessa camada cuticular. A densidade de tricomas apresenta-se distinta entre as espécies. Os estômatos ocorrem em uma ou ambas as faces da folha estando as células estomáticas situadas ao mesmo nível ou ligeiramente abaixo das demais. Tecidos aquíferos foram observados em todas as espécies estudadas, assim como cristais, fibras e estruturas secretoras. A estrutura do mesofilo varia entre as espécies, sendo dorsiventral, isobilateral ou Kranz. Em todas as espécies estudadas foram identificados caracteres xeromorfos.
\end{abstract}

Palavras-chave: anatomia foliar, ambiente salino, planícies costeiras arenosas (restinga).

\section{Abstract}

(Leaf anatomy of halophytes and psammophilous plants from the Restinga of Ipitangas, Saquarema, Rio de Janeiro, Brazil) The present study deals with the leaf anatomy of Blutaparon portulacoides (A. St.-Hil.) Mears. (Amaranthaceae), Ipomoea pes-caprae (L.) R. Br. and I. imperati (Vahl) Griseb. (Convolvulaceae), Canavalia rosea (Sw.) DC. and Sophora tomentosa L. (Leguminosae), Sporobolus virginicus (L.) Kunth (Poaceae) and Miegia maritima (Aubl.) Willd. (Cyperaceae). Most investigated species have succulent leaves and single-layered epidermis coated with a thick cuticle. Trichome densities varied among the studied species. Stomata are present on only one or both surfaces and the guard cells occur at same level of the epidermal layer or in depressions. Aquiferous tissues are observed in all species, as well as fibers, crystals and secretory structures. The mesophyll has dorsiventral, isobilateral or Kranz strutucture, according to the species. The leaf structure of all studied species has shown xeromorphic characters.

Key words: leaf anatomy, saline environment, sandy coastal plains ("restinga").

\section{INTRODUÇÃO}

Os solos são considerados salinos quando a concentração de sais é igual ou excede a $0,5 \%$, e correspondem a aproximadamente $6 \%$ da superfície dos continentes (Larcher 1995, Street \& Öpik 1984). Estes ocorrem em regiões áridas, onde a precipitação é menor que a evaporação, nas porções tropicais costeiras que apresentam grande aporte de sais oriundos do mar (Larcher 1995), ou ainda, quando intensamente utilizados pela agricultura (Koyro 2006).
As plantas capazes de tolerar ambientes salinos são denominadas halófitas e ocupam, em geral, locais pobres em nutrientes e submetidos à forte luminosidade (Dickison 2000). Sob tais condições estas espécies podem apresentar alterações morfológicas, como aumento da suculência; ou fisiológicas, como diminuição na condutância estomática e acúmulo de solutos orgânicos no citoplasma, tais como, sorbitol, polióis, prolina, betaína, entre outros (Kozlowski 1997; Koyro 2006).

Artigo recebido em 04/2008. Aceito para publicação em 02/2009.

${ }^{1}$ Universidade Federal do Estado do Rio de Janeiro (UNIRIO), Escola de Ciências Biológicas, Depto. Botânica, Av. Pasteur 458, 21290-240, Rio de Janeiro, RJ, Brasil. rosaniarruda@ gmail.com

${ }^{2}$ Universidade do Estado do Rio de Janeiro, Faculdade de Formação de Professores, Campus São Gonçalo, Depto. Ciências. R. Francisco Portela 794, 24435-000, São Gonçalo, RJ, Brasil. anaangbarros@gmail.com 
Estudos envolvendo estratégias de sobrevivência sob salinidade têm sido realizados no mundo todo, considerando-se o interesse no reconhecimento das estruturas morfo-anatômicas que permitem a determinadas espécies a ocupação de regiões extremamente salinas (Costa et al. 2003; Ramadan 1998; Gucci et al. 1997). Em diferentes partes do mundo, as halófitas têm sido investigadas tendo em vista que a intensificação da agricultura, o uso indevido da água, combinado com a alta evapotranspiração, têm contribuído fortemente para salinização dos solos (Koyro 2006; Flowers \& Flowers 2005).

No estado do Rio de Janeiro encontram-se solos salinos em formações geológicas litorâneas recentes, adjacentes ao oceano, denominadas restingas (Suguio \& Tessler 1984; Araujo \& Henriques 1984). Um dos aspectos mais notáveis desse ecossistema é a distribuição da vegetação em zonas ou comunidades, a partir da linha da costa (Pfadenhauer 1978), destacando-se as comunidades das halófitas e psamófilas reptantes, constituídas por plantas constantemente submetidas ao contato com a água do mar e à mobilidade do substrato. Em ambientes arenosos como as restingas, altas temperaturas, associadas a ventos constantes, são apontados como a causa da elevada evapotranspiração contribuindo para o aumento da salinidade do solo (Pammenter 1984). As planícies litorâneas são pobres em argila e matéria orgânica, evidenciando mínima capacidade de retenção de nutrientes e água (Scarano 2002). Nesses locais, a entrada de nutrientes ocorre, principalmente, pela deposição aérea, sendo a vegetação o principal elemento com a capacidade de retê-los, tornando-os disponíveis para utilização pelos demais componentes da flora (Hay \& Lacerda 1984; Reinert et al. 1997; Mantovani \& Iglesias 2001).

Relativamente poucos são os trabalhos disponíveis na literatura relacionados à anatomia de espécies das comunidades de halófitas e psamófilas reptantes das restingas fluminenses. Para uma área de dunas no litoral de Santa Catarina, Boeger \& Gluzezak (2006) identificaram o predomínio de halófitas e psamófilas, prostradas, verticalmente orientadas em relação ao solo, com folhas suculentas, anfiestomáticas, dentre outras peculiaridades. Alguns dos caracteres levantados indicaram a importância da estrutura anatômica da folha para a colonização e sobrevivência em um ambiente marcado pela mobilidade do substrato, baixa disponibilidade de matéria orgânica, drenagem rápida da água e intensa luminosidade.

Esse trabalho tem como objetivo identificar as características anatômicas das folhas de halófitas e psamófilas reptantes presentes na Restinga de Ipitangas, Saquarema, RJ. Pretende-se identificar os elementos anatômicos potencialmente importantes para a sobrevivência dessa vegetação em um ambiente submetido a altas temperaturas, elevada intensidade luminosa, herbivoria, deficiência hídrica e nutricional.

\section{Material e Métodos}

O material botânico foi coletado na Restinga de Ipitangas, localizada no município de Saquarema no estado do Rio de Janeiro ( $\left.22^{\circ} 55^{\prime} \mathrm{S} ; 42^{\circ} 26^{\prime} \mathrm{W}\right)$. Essa região compreende um sistema formado por planícies arenosas com vegetação de restinga, terrenos alagadiços e a Lagoa de Jacarepiá. É parte integrante da Área de Proteção Ambiental da Massambaba e constitui a Reserva Ecológica Estadual de Jacarepiá, criada pelo Decreto Estadual $n^{\circ}$ 9.529-A, de 15/12/1986, abrangendo uma área de 1.267 ha. (Araujo et al 2009; Sá 1993).

Araujo (2000) dividiu as restingas fluminenses em quatro regiões e incluiu Ipitangas na Região dos Lagos, integrada ao Centro de Diversidade Vegetal de Cabo Frio. O clima é sub-úmido com precipitações médias anuais de $823 \mathrm{~mm}$, temperatura média de $22,9^{\circ} \mathrm{C}$ e umidade relativa do ar de 83\% (Sá 1993; Sá \& Araujo 2009). A Restinga de Ipitangas é formada por duplo cordão arenoso entre os quais existe uma depressão brejosa que se estende, paralelamente à linha da costa, por cerca de três quilômetros (Sá 1993; Sá \& 
Araujo 2009). Nesta região foram identificadas as seguintes comunidades vegetais: halófitas, psamófilas reptantes, "scrub" de Palmae, brejo herbáceo e floresta seca.

Para o desenvolvimento do estudo foram coletadas amostras de plantas procedentes das comunidades de halófitas e psamófilas reptantes relacionadas na Tabela 1 . O material testemunho foi depositado no Herbário da Faculdade de Formação de Professores, UERJ (RFFP).

Para a análise anatômica foram empregadas folhas e/ou folíolos expostos ao sol, plenamente expandidos, provenientes do terceiro e quarto nós, a partir do ápice do ramo, retirados de quatro a cinco indivíduos, separados entre si por uma distância de pelo menos 5,0 metros, ao longo da linha da praia, e ocorrentes na zona atingida pela maré nos períodos mais altos.

O material foi fixado em FAA 50 (Johansen 1940) durante 48 horas, e conservado em etanol a 70\%. Para obtenção de lâminas permanentes, foram empregados segmentos retirados das seguintes regiões: intercostal (entre nervura principal e bordo, inclusive), nervura central, pecíolo ou peciólulo e bainhas foliares retirados da porção mediana de cada parte. Os segmentos foliares foram submetidos à desidratação em série etanolbutanólica, infiltrados em parafina e cortados com espessura de 12-20 $\mu \mathrm{m}$, em micrótomo rotativo nos planos transversal, paradérmico e longitudinal. Os cortes foram corados em azul de alcião em ácido tartárico $1 \%$ e fucsina ácida 1\% (Kraus \& Arduin 1997). A epiderme foi descrita utilizando-se segmentos foliares de 0,5 $\mathrm{cm}^{2}$, dissociados em peróxido de hidrogênio e ácido acético, seguindo-se as modificações citadas por Kraus \& Arduin (1997), em tempos variáveis, conforme a consistência da folha, procedentes das mesmas regiões empregadas na obtenção das secções transversais, paradérmicas e longitudinais. As epidermes dissociadas foram coradas em safranina $1 \%$ ou fucsina básica $0,25 \%$ em etanol $50 \%$ e montadas em glicerina 50\%. Para observação de detalhes da vascularização foliar, hidatódios e mesofilo foram preparadas diafanizações segundo o método de Foster (1950). Para identificação de compostos da parede, citoplasma ou vacúolo, foram realizados os

Tabela 1 - Lista das famílias e espécies estudadas na Restinga de Ipitangas, Saquarema, Rio de Janeiro, números de coletor e comunidade vegetal a que pertencem de acordo com a classificação de Sá (1993).

Table 1 - Plant families and species surveyed at the sandy coastal plains (restinga) of Ipitangas, municipality of Saquarema, Rio de Janeiro. Numbers of the collector and respective comumnity following the classification of Sá(1993).

\begin{tabular}{|c|c|c|c|}
\hline Família & Espécie & Número do Coletor & $\begin{array}{c}\text { Comunidade } \\
\text { Vegetal }\end{array}$ \\
\hline Amaranthaceae & $\begin{array}{l}\text { Blutaparon portulacoides } \\
\text { (A. St. Hil.) Mears. }\end{array}$ & A.A.M. de Barros 2622 et al. & halófitas \\
\hline \multirow[t]{2}{*}{ Convolvulaceae } & Ipomoea imperati (Vahl) Griseb. & R. C. O. Arruda 013 et al. & $\begin{array}{l}\text { psamófilas } \\
\text { reptantes }\end{array}$ \\
\hline & Ipomoea pes-caprae (L.) Sweet & A.A.M. de Barros 2619 et al. & halófitas \\
\hline Cyperaceae & Miegia maritima (Aubl.) Willd. & R. C. O. Arruda 017 et al. & $\begin{array}{l}\text { psamófilas } \\
\text { reptantes }\end{array}$ \\
\hline \multirow[t]{2}{*}{ Leguminosae } & Canavalia rosea (Sw.) DC. & A.A.M. de Barros 2620 et al. & $\begin{array}{l}\text { psamófilas } \\
\text { reptantes }\end{array}$ \\
\hline & Sophora tomentosa L. & A.A.M. de Barros 2621 et al. & $\begin{array}{l}\text { psamófilas } \\
\text { reptantes }\end{array}$ \\
\hline Poaceae & Sporobolus virginicus (L.) Kunth & R. C. O. Arruda 015 et al. & halófitas \\
\hline
\end{tabular}


seguintes testes histoquímicos, em cortes a mão livre, de material recém coletado: cloreto de zinco iodado para identificação de celulose (Jensen 1962); floroglucinol clorídrico para lignina (Sass 1951); lugol para amido (Sass 1951); Sudan IV para identificação de cutina e de substâncias de natureza lipídica (Sass 1951); cloreto férrico para compostos fenólicos (Johansen 1940); vermelho de rutênio para identificação de substâncias pécticas (Strasburger 1924). Para identificação da composição de cristais foram realizados testes com ácido acético $10 \%$ e ácido clorídrico $10 \%$ para oxalato de cálcio, e cristais de fenol em óleo de cravo para reconhecimento de silicato (Johansen 1940).

\section{Resultados}

As células epidérmicas, em ambas as faces da lâmina foliar, apresentam paredes anticlinais retas e espessadas em I. pes-caprae, I. imperati, C. rosea e S. tomentosa (Figs. 1, 2). Em B. portulacoides mostram-se levemente sinuosas na face adaxial (Fig. 1e). $\mathrm{Na}$ face abaxial da folha de $M$. maritima, e nas duas faces da folha de $S$. virginicus (Fig. 1f), a epiderme se organiza em faixas costais (FC, sobre nervuras) e intercostais (FIC, entre nervuras). As células epidérmicas das faixas intercostais têm paredes anticlinais sinuosas e as demais apresentam paredes retas (Fig. 1f). Em B. portulacoides, na face abaxial, as células epidérmicas comuns também mostram paredes retas (Fig. 2a).

Tricomas tectores unicelulares ocorrem em parte das espécies estudadas, distribuídos em uma ou ambas as faces da lâmina foliar de $C$. rosea, $S$. virginicus (Figs. 1c,f) e $M$. maritima. Em $S$. tomentosa os tricomas são pluricelulares unisseriados, formados por uma célula apical volumosa, com paredes delgadas e de duas a seis células, organizadas em série, no nível da epiderme. Na face adaxial notam-se as cicatrizes deixadas pela queda da porção apical (Fig. 1d). Na face abaxial os tricomas formam um denso indumento protegendo os estômatos (Fig. 2b,b'). Em S. virginicus, os tricomas estão restritos às faixas intercostais. Em $M$. maritima tricomas tectores ocorrem apenas no bordo.

Tricomas glandulares pluricelulares são observados em I. pes-caprae, I. imperati e $C$. rosea (Figs. 1a-c, 2c).

Com relação à localização dos estômatos, as folhas das plantas estudadas podem ser classificadas em epiestomática em $B$. portulacoides, anfiestomática em I. imperati, I. pes-caprae e C. rosea, ou hipoestomática em M. maritima e S. tomentosa. S. virginicus apresenta folhas anfiestomáticas, com maior densidade de estômatos na face superior da lâmina. Em S. virginicus e M. maritima (Fig. 2d) os estômatos se organizam em fileiras paralelas ao comprimento da folha. Nas demais espécies distribuem-se aleatoriamente.

Em C. rosea foram identificadas, em ambas as faces da lâmina, pares de células epidérmicas contendo cada uma, um cristal retangular de oxalato de cálcio (Figs. 1c, 2ef). Em S. tomentosa são observados cristais de várias formas, incluídos nas células epidérmicas comuns (Fig. 1d). Os testes histoquímicos realizados não permitiram o reconhecimento da natureza dessas estruturas, que em certas regiões da folha ocorrem também nas camadas subepidérmicas. Corpos silicosos cônicos organizados em filleiras foram verificados em células epidérmicas longas da face abaxial da lâmina foliar de M. maritima (Fig. 2d). Em S. virginicus os corpos de sílica ocorrem no interior de células retangulares presentes nas faixas costais e intercostais de ambas as faces da folha.

A posição do complexo estomático em relação às demais células epidérmicas pode variar, de acordo com a espécie, situando-se em nível ligeiramente inferior na epiderme de B. portulacoides (Fig. 3a) ou ao mesmo nível dos demais componentes da epiderme como em I. imperati (Fig. 3c) e M. maritima. Em C. rosea, I. pes-caprae e S. tomentosa (Fig. 3d-f) os estômatos encontram-se mais protegidos. Em S. virginicus os estômatos se localizam em sulcos na epiderme e em nível inferior. 


\begin{tabular}{|c|c|c|c|c|c|c|c|}
\hline Caráter/Espécie & B. portulacoides & C. rosea & I. pes-caprae & I. imperati & M. maritima & S. tomentosa & S. virginicus \\
\hline $\begin{array}{l}\text { Aspecto da parede } \\
\text { anticlinal }\end{array}$ & reta e delgada & $\begin{array}{l}\text { reta e } \\
\text { espessada }\end{array}$ & $\begin{array}{l}\text { reta e } \\
\text { espessada }\end{array}$ & $\begin{array}{l}\text { reta e } \\
\text { espessada }\end{array}$ & $\begin{array}{l}\text { sinuosa e } \\
\text { espessada }\end{array}$ & $\begin{array}{l}\text { reta e } \\
\text { espessada }\end{array}$ & $\begin{array}{l}\text { parte sinuosa e parte } \\
\text { reta, espessada }\end{array}$ \\
\hline Tricoma tector & ausente & presente & ausente & ausente & presente & presente & presente \\
\hline Tricoma glandular & ausente & presente & presente & presente & ausente & ausente & ausente \\
\hline $\begin{array}{l}\text { Classificação da folha } \\
\text { em relação à } \\
\text { localização dos } \\
\text { estômatos }\end{array}$ & epiestomática & anfiestomática & anfiestomática & anfiestomática & hipoestomática & hipoestomática & anfiepiestomática \\
\hline $\begin{array}{l}\text { Células epidérmicas } \\
\text { com cristais }\end{array}$ & ausentes & presentes & ausentes & ausentes & presentes & presentes & presentes \\
\hline $\begin{array}{l}\text { Nivelamento do } \\
\text { complexo estomático } \\
\text { na epiderme }\end{array}$ & abaixo & abaixo & abaixo & mesmo nível & mesmo nível & abaixo/papilas & abaixo/criptas \\
\hline $\begin{array}{l}\text { Células epidérmicas } \\
\text { volumosas }\end{array}$ & presentes & ausentes & presentes & presentes & presentes & presentes & presentes \\
\hline Células buliformes & ausentes & ausentes & ausentes & ausentes & presentes & ausentes & presentes \\
\hline
\end{tabular}



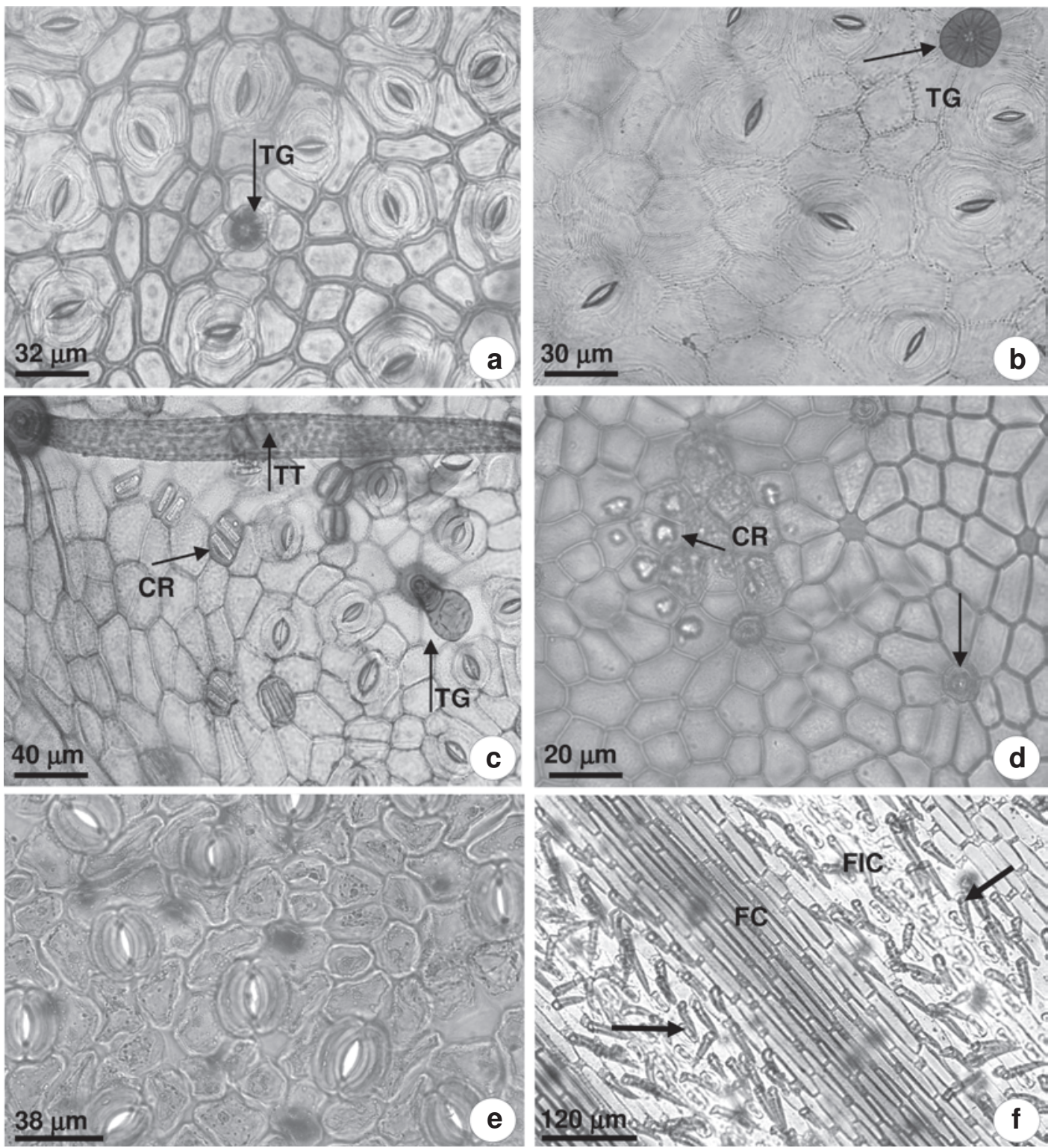

Figura 1 - Epiderme foliar da face adaxial em vista frontal - a. Ipomoea pes-caprae, células epidérmicas comuns com paredes anticlinais retas e espessadas, estômatos e tricoma glandular (TG); b. I. imperati, com destaque para o tricoma glandular (TG); c. Canavalia rosea, tricoma glandular (TG), estômatos, células com cristais (CR) e tricoma tector (TT); d. Sophora tomentosa, células epidérmicas com paredes anticlinais retas, algumas com cristais (CR), e cicatriz de tricoma (seta); e. Blutaparon portulacoides, estômatos e células epidérmicas com paredes anticlinais sinuosas; f. Sporobolus virginicus, organização da epiderme em faixas costais (FC) e intercostais (FIC). Numerosos tricomas tectores ocorrem nas faixas intercostais (setas).

Figure 1 - Adaxial surface of the leaf epidermis. Frontal view - a. Ipomoea pes-caprae, common epidermal cells with straight and thickned anticlinal walls, stomata and glandular trichome (TG); b. I. imperati, detail of the glandular trichome (TG); c. Canavalia rosea, detail of the glandular trichome (TG), stomata, crystal idioblasts (CR) and non-glandular trichome (TT); d. Sophora tomentosa, anticlinal epidermal cells with straigth walls, crystal idioblasts (CR), and scars left by detached trichome (arrow); e. Blutaparon portulacoides, stomata and epidermal cells with sinuous naticlinal walls; f. Sporobolus virginicus, epidermal cells arranged in coastal (FC) and intercoastal (FIC) bands. Several non-glandular trichomes occur on the intercoastal bands (arrows). 


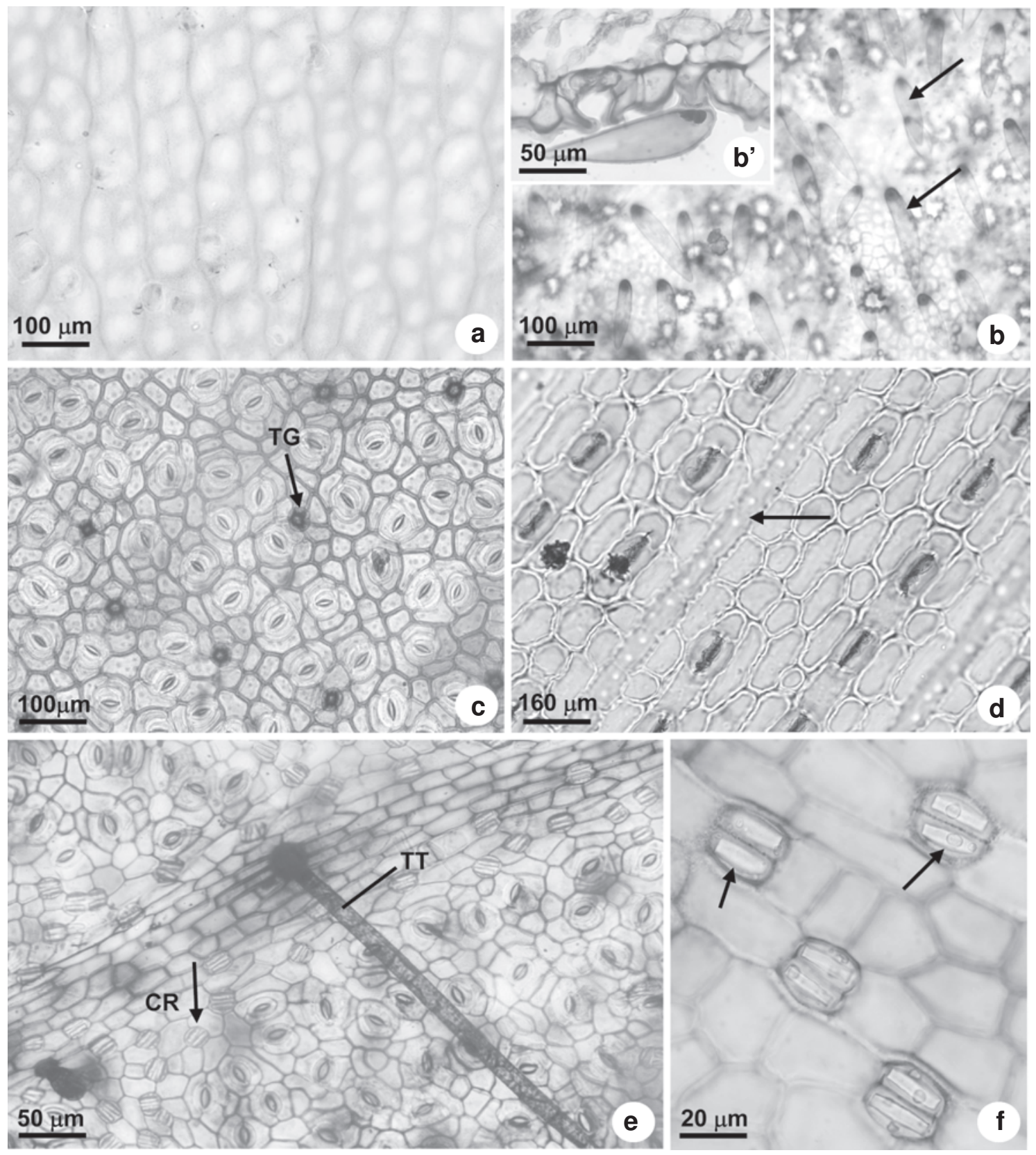

Figura 2 - Epiderme foliar da face abaxial em vista frontal - a. células epidérmicas comuns de Blutaparon portulacoides com paredes anticlinais retas; b. Sophora tomentosa com destaque para os tricomas tectores (setas); b'. detalhe do tricoma tector; c. Ipomoea pes-caprae, estômatos e tricoma glandular (TG); d. Miegia maritima, células epidérmicas com cristais de sílica (seta); e. Canavalia rosea, células epidérmicas comuns com paredes retas sobre nervura, estômatos, cristais em células epidérmicas (CR), e parte do tricoma tector (TT); f. C. rosea com destaque para pares de células epidérmicas com cristais retangulares (setas).

Figure 2 - Abaxial surface of the leaf epidermis. Frontal view - a. common epidermal cells with straight anticlinal walls of Blutaparon portulacoides; b. Sophora tomentosa, uniseriate trichomes (arrows); b'. non-glandular trichome; c. Ipomoea pescaprae, stomata and glandular trichome (TG); d. Miegia maritima, epidermal cells with silica (arrow); e. Canavalia rosea, common epidermal cells with straigth anticlinal walls over midrib, stomata, crytal idioblasts in the leaf epidermis (CR), and detail of a non-glandular trichome (TT); f. C. rosea,showing paired epidermal cells with rectangular crystals (arrows). 
Todas as espécies investigadas apresentam epiderme unisseriada, quando observadas em secção transversal. A camada de cuticular é espessada em I. pes-caprae, I. imperati, $C$. rosea, $S$. tomentosa, $M$. maritima e $S$. virginicus e delgada em $B$. portulacoides (Fig. 3a). Internamente à epiderme da face adaxial de $S$. tomentosa ocorre uma hipoderme formada por células aclorofiladas, volumosas e de paredes finas constituindo um tecido aquífero (Fig. 3e). A secção transversal evidencia que os tricomas glandulares inserem-se na epiderme através de um pedículo bicelular em I. pes-caprae e I. imperati (Fig. 3g), e com até três células em C. rosea (Fig. 3b). Esses tricomas contêm substâncias de natureza fenólica e lipídica.

Em B. portulacoides, $S$. tomentosa, I. pes-caprae, I. imperati e em $M$. maritima as células epidérmicas comuns são volumosas, retangulares, apresentando paredes periclinais primárias bastante espessadas (Figs. 3a,c-e). Em S. tomentosa as células epidérmicas da face abaxial formam projeções papilosas (Fig. 3f).

No mesofilo, o parênquima paliçádico é bastante desenvolvido, voltado para uma ou ambas as faces da lâmina, resultando em variações na estrutura foliar; em três das espécies estudadas evidencia-se o padrão Kranz (Tab. 3). Em I. imperati e I. pescaprae ocorrem de cinco a 12 camadas de parênquima paliçádico voltadas para as duas faces da folha, caracterizando a estrutura isolateral (Figs. 3c,d). Em C. rosea encontram-se de quatro a sete camadas deste tecido, com células volumosas na face adaxial, e estreitas na abaxial (estrutura isolateral). Em $S$. tomentosa ocorrem duas a três camadas de parênquima paliçádico voltadas para a face adaxial evidenciando o padrão dorsiventral (Fig. 3e). Nessas espécies o parênquima esponjoso é bem desenvolvido e formado por células clorofiladas entre as quais existem amplos espaços intercelulares. Em B. portulacoides, M. maritima e em $S$. virginicus identifica-se a síndrome Kranz (Figs. 3a,h; 4a-c). As células do clorênquima têm paredes extremamente delgadas e se dispõem exclusivamente em torno da endoderme, como em B. portulacoides (Fig. 3h) e M. maritima (Figs. 4c,d), ou em volta das células da extensão parenquimática, como notado nos feixes de maior porte de $S$. virginicus (Figs. 4a,b). Em M. maritima as células da endoderme têm paredes espessadas e lignificadas (Fig. 4d), enquanto que em $B$. portulacoides e $S$. virginicus a endoderme tem células com paredes espessadas, não lignificadas e clorofiladas (Figs. 3a, 4b). Internamente à endoderme de $S$. virginicus e $M$. maritima encontra-se uma camada parenquimática com células também clorofiladas correspondendo ao periciclo (Figs. 4c,d).

$\mathrm{Na}$ lâmina foliar das espécies investigadas o tecido de reserva de água pode ser composto pela hipoderme aquífera, observada em $S$. tomentosa, ou por um parênquima aquífero aclorofilado, apresentando células de paredes finas, e localizado em diferentes posições na lâmina foliar (Tab. 3). Em B. portulacoides o parênquima aquífero é muito desenvolvido ocupando mais de $2 / 3$ da espessura da folha, voltado para face abaxial da lâmina (Fig. 3a). Em M. maritima este tecido é composto por camadas de células de paredes primárias espessadas e ocorre voltado para a face adaxial; numerosos idioblastos contendo fenóis ocorrem dispersos no tecido aquífero (Fig. 4c). Na folha de I. pes-caprae e I. imperati o parênquima aquífero é abundante, localizado na porção mediana do mesofilo e em torno do sistema vascular, formando camadas que envolvem e unem os feixes à epiderme (Figs. 3c,d). O tecido de reserva de água pode localizar-se também no bordo (Figs. 4e-g).

Em todas as espécies estudadas o sistema vascular é formado por feixes condutores do tipo colateral. A posição do sistema vascular é variável podendo se localizar voltado para a face superior, na região central ou nas proximidades da face abaxial da folha (Tab. 3). Em B. portulacoides o sistema vascular situa- 

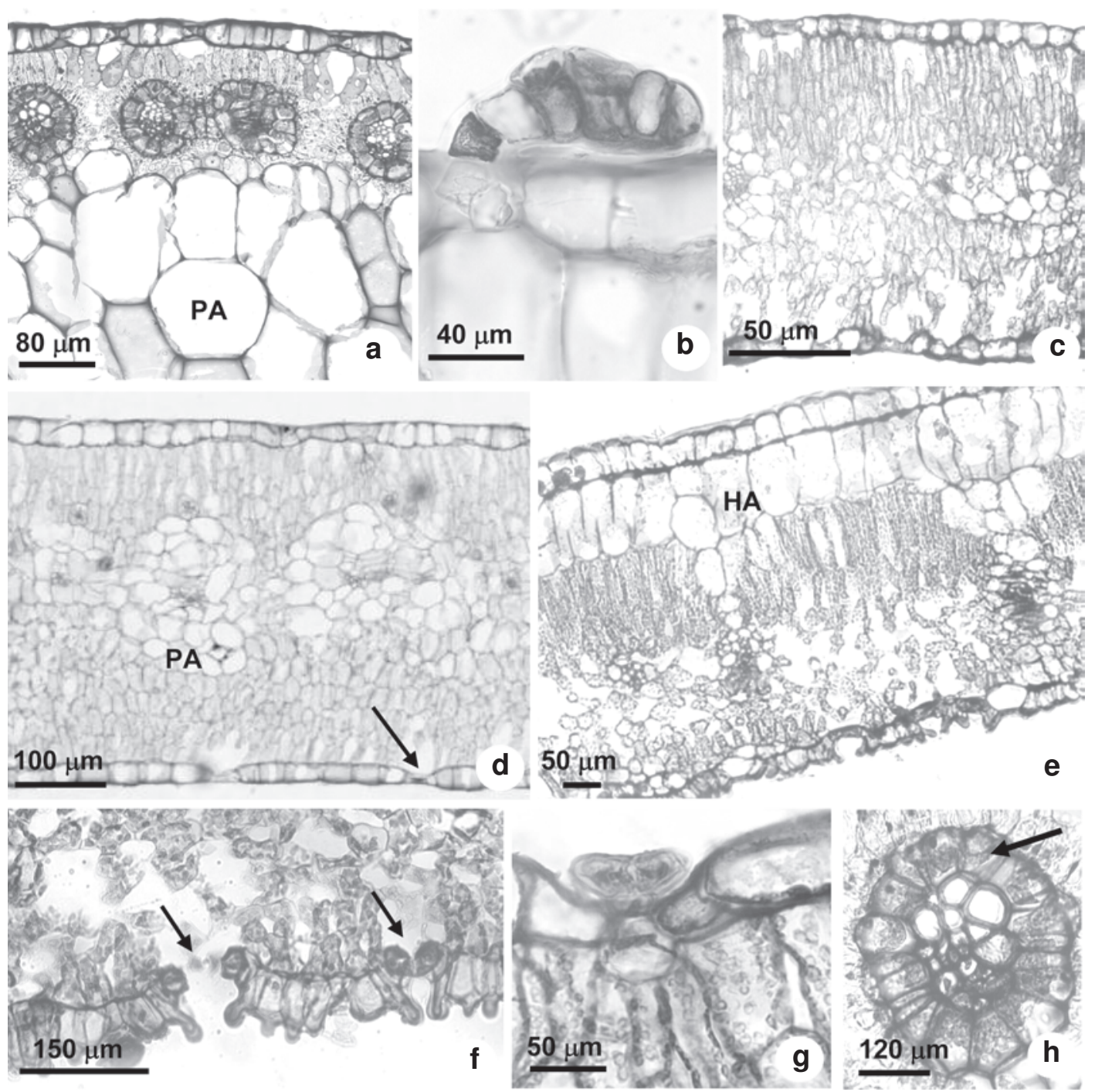

Figura 3 - Lâmina foliar em secção transversal - a. Blutaparon portulacoides, clorênquima radiado voltado para a face superior da lâmina e parênquima aquífero na face oposta (PA); b. detalhe do tricoma glandular pluricelular de Canavalia rosea; c. Ipomoea imperati, estrutura isolateral; d. I. pes-caprae, estrutura isolateral e células do parênquima aquífero (PA) na porção central da lâmina; a seta aponta a localização de um estômato; e. Sophora tomentosa, estrutura dorsiventral, hipoderme aquifera (HA) e feixes com extensões parenquimáticas; f. S. tomentosa, detalhe das células do parênquima esponjoso, estômatos protegidos (setas) por células epidérmicas papilosas; g. detalhe do tricoma glandular pluricelular de Ipomoea imperati; h. B. portulacoides, detalhe de um feixe vascular envolvido por endoderme cujas células têm paredes espessadas (seta).

Figure 3 - Cross section of leaf lamina - a. Blutaparon portulacoides radiated chlorenchyma adjacent to the adaxial surface; aquiferous parenchyma near the abaxial surface (PA); b. pluricellular glandular trichome of Canavalia rosea; c. Ipomoea imperati, isolateral mesophyll structure; d. I. pes-caprae, isolateral mesophyll. Aquiferous parenchyma cells (PA) on the center of leaf lamina; arrow indicates stomata; e. Sophora tomentosa, mesophyll dorsiventral structure, aquiferous hypodermis (HA) and vascular bundles with parenchymatic extensions; f. S. tomentosa, spongy cells, stomata hindered (arrow) by papillose epidermal cells; g. pluricellular glandular trichome of Ipomoea imperati; h. B. portulacoides, vascular bundle surrounded by endodermal cells with thickened walls (arrow). 
se nas proximidades da face adaxial (Fig. 3a) e em $S$. virginicus e $M$. maritima está voltado para a face abaxial (Figs. 4a,c). Nas demais espécies, os feixes condutores localizam-se na porção mediana do mesofilo. Fibras lignificadas aparecem associadas em pequenas proporções ao sistema vascular de $S$. tomentosa, constituindo parte da extensão de bainha. $\mathrm{Na}$ folha de $S$. virginicus notam-se grupos de fibras subepidérmicas nas regiões costais, formando extensões esclerenquimáticas (Figs. 4a,b). Em M. maritima observam-se grupos de fibras lignificadas formando calotas subepidérmicas em torno de toda a lâmina foliar (Fig. 4c).

Todas as espécies analisadas mostram reação positiva à presença de substâncias fenólicas com destaque para $C$. rosea e $M$. maritima (Fig. 4c,d). Canais laticíferos, contornados por células epiteliais de paredes delgadas, são observados em I. pes-caprae e I. imperati. Drusas são encontradas no mesofilo de B. portulacoides, I. pes-caprae e $I$. imperati, e cristais romboédricos em $C$. rosea e $S$. tomentosa, inclusive nas células das extensões de bainha dos feixes vasculares.

Hidatódios podem ser observados em $I$. pes-caprae, I. imperati e C. rosea. Em I. pescaprae e I. imperati a estrutura secretora localiza-se no ápice da nervura central constituindo um apêndice (Fig. 4h). Em C. rosea o hidatódio também se situa no ápice da nervura formando uma protuberância (Fig. 4i). Nas três espécies citadas a estrutura de secreção é constituída por um conjunto de traqueídes com espessamentos reticulados, inseridas em um epitema parenquimático (Fig. 4j); na epiderme do apêndice de I. imperati alguns estômatos de grandes dimensões foram observados. $\mathrm{Na}$ epiderme do bordo da folha de Miegia maritima evidenciam-se tricomas unicelulares com paredes espessadas e silicificadas (Fig. 5a).

\section{Região da Nervura Central}

A região central da lâmina foliar de $M$. maritima e $S$. virginicus evidencia a presença de epiderme composta por células buliformes na face adaxial (Fig. 5b). Nas demais espécies a nervura principal é recoberta por células epidérmicas comuns com paredes retas e espessadas.

Na região cortical de $S$. tomentosa, $C$. rosea, I. pes-caprae e I. imperati observamse camadas de células parenquimáticas clorofiladas nas porções próximas à epiderme e aclorofiladas internamente, semelhantes a um tecido aquífero (Fig. 5c). Idioblastos cristalíferos semelhantes aos descritos para o mesofilo podem ser encontrados no córtex. O sistema vascular é composto por feixes colaterais em B. portulacoides, M. maritima, C. rosea, S. virginicus e $S$. tomentosa, e bicolaterais em $I$. pes-caprae (Fig. 5i) e I. imperati. Em $C$. rosea a nervura central está completamente envolvida por fibras pericíclicas lignificadas e em $S$. tomentosa este tipo de célula forma uma calota na face abaxial do feixe.

Em I. pes-caprae e I. imperati nota-se o desenvolvimento de colênquima sob a epiderme e numerosos canais laticíferos no córtex.

\section{Pecíolo, peciólulo e bainhas foliares}

Em vista frontal, a epiderme do pecíolo de B. portulacoides, I. pes-caprae, I. imperati e peciólulo de $S$. tomentosa e $C$. rosea é composta por células comuns com paredes retas, que tendem a se organizar em fileiras paralelas ao comprimento da folha. Estômatos e tricomas glandulares podem ser observados em I. pes-caprae (Figs. 5e) e $I$. imperati. Em C. rosea (Fig. 5f) e S. tomentosa notam-se tricomas tectores em grande quantidade, idênticos aos descritos para a região intercostal da lâmina. Na bainha foliar de M. maritima e S. virginicus ocorrem células epidérmicas silicosas semelhantes às observadas na lâmina. Estômatos aparecem enfileirados na face abaxial da epiderme das duas espécies mencionadas.

A seção transversal evidencia que, em todas as espécies, a epiderme dos pecíolos, peciólulos ou bainhas foliares é unisseriada e tem características bastante similares às descritas para a região intercostal. Em $S$. 

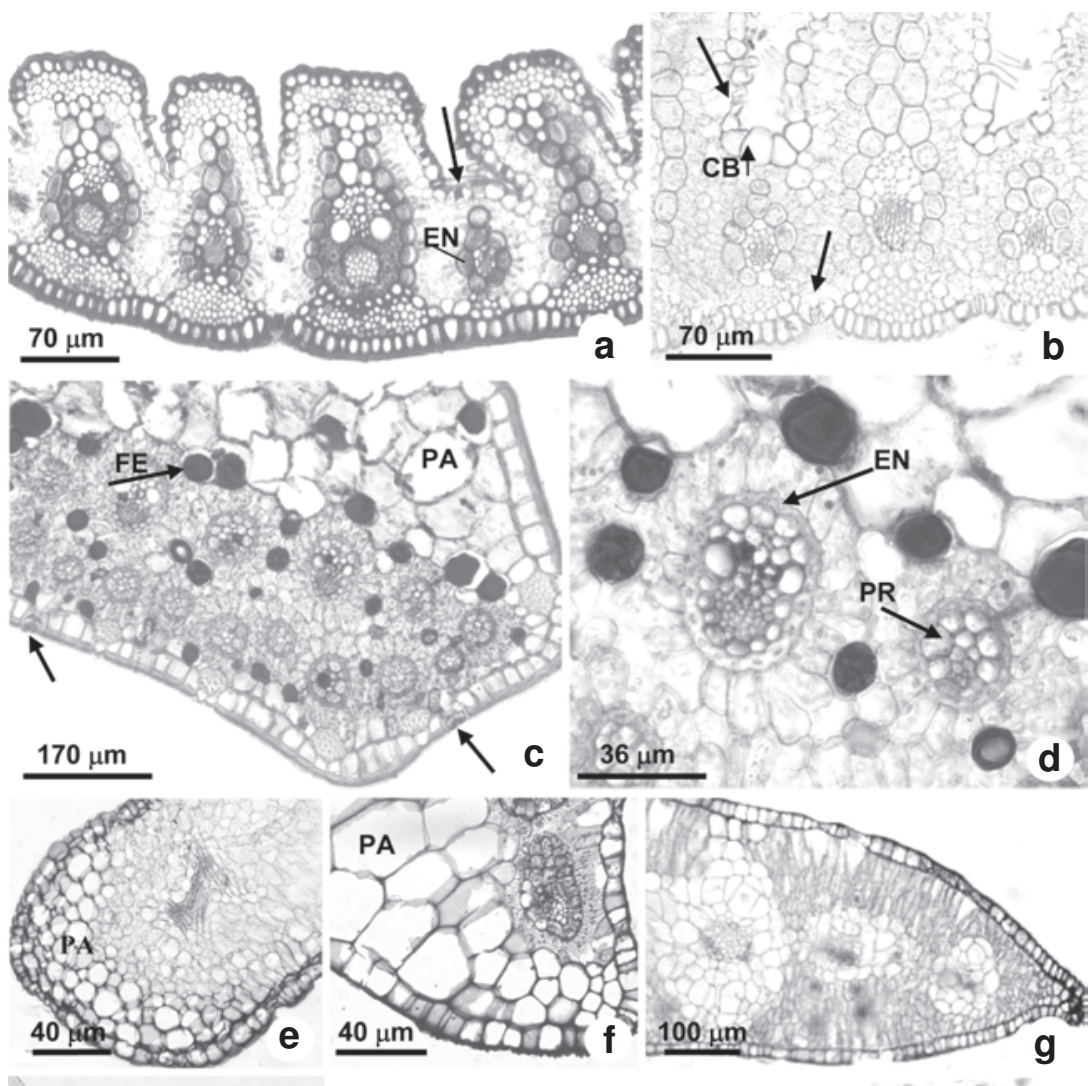
$70 \mu \mathrm{m}$

b
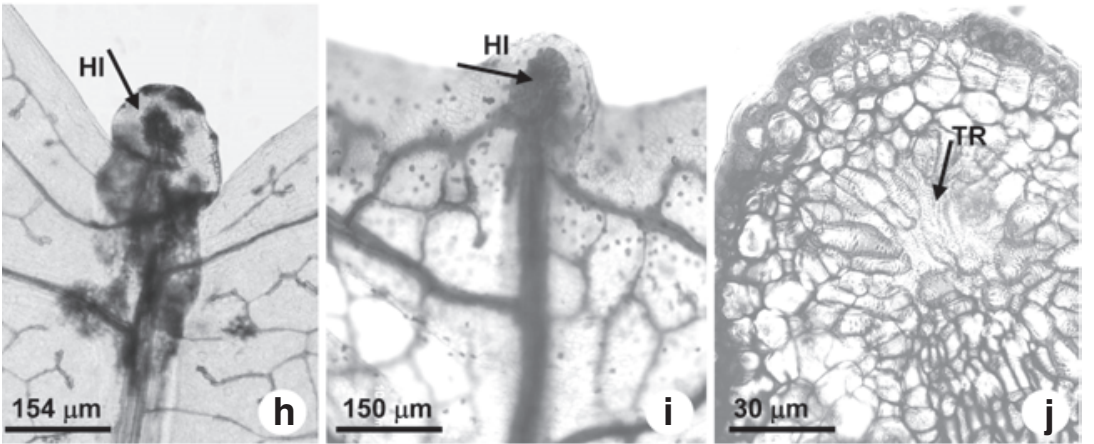

Figura 4 - Lâmina foliar em secção e folha diafanizada - a. Sporobolus virginicus, face adaxial com sulcos, clorênquima radiado, endoderme clorofilada (EN) e estômato na face adaxial (seta); b. detalhe da epiderme e mesofilo de S. virginicus, células buliformes (CB), clorênquima radiado e estômatos (setas); c. Miegia maritima, parênquima aquífero (PA) voltado para a face adaxial, feixes vasculares e clorênquima radiado para a face oposta; idioblastos com fenóis (FE) e estômatos (setas); d. detalhe do mesofilo de M. maritima, clorênquima em torno dos feixes vasculares, endoderme com paredes espessadas (EN) e periciclo parenquimático (PR). e-g. Bordos - e. Canavalia rosea; f. Blutaparon portulacoides; g. Ipomea pes-caprae. h-i. - Folhas diafanizadas, detalhe da região apical da nervura principal evidenciando hidatódios (HI) - h. I. pes-caprae; i. Canavalia rosea; j. secção paradérmica da folha de C. rosea mostrando traqueídes constituintes do hidatódio (TR).

Figure 4 - Leaf lamina, cross section and diaphanization - a. Sporobolus virginicus, adaxial surface sulcated, radiated chlorenchyma, endodermal cells with chloroplasts (EN) and stomata at adaxial surface (arrow); b. epidermis and mesophyll of S. virginicus in detail, showing bulliform cells (CB), radiated chlorenchyma and stomata (arrows); c. Miegia maritima, aquiferous parenchyma (PA) near the adaxial surface, vascular bundles and radiated chlorenchyma near the abaxial surface; idioblast with phenolic compounds (FE) and stomata (arrows); d. mesophyll of M. maritima, clorenchyma surrounding vascular bundles, endodermal cells with thick walls (EN) and pericycle composed by parenchymatic cells (PR). e-g. Leaf margins - e. Canavalia rosea; f. Blutaparon portulacoides; g. Ipomea pes-caprae. h-i. Diaphanized leaves, detail of the midrib apical region showing hydathodes $(\mathrm{HI})$ - h. I. pes-caprae; i. Canavalia rosea; j. C. rosea, paradermal section showing tracheids of the hydathode (TR). 
virginicus e $M$. maritima a bainha foliar é preenchida por células de parênquima aclorofilado (Fig. 5g). Na região cortical do peciólulo de $S$. tomentosa, C. rosea (Fig. 5h), pecíolo de I. pes-caprae e I. imperati (Fig. 5i) encontra-se um amplo desenvolvimento de tecido aquífero aclorofilado. $\mathrm{O}$ córtex externo do pecíolo das duas últimas espécies citadas é ocupado por camadas de colênquima angular (Fig. 5i).

O sistema vascular do pecíolo de $B$. portulacoides é composto por feixes colaterais e está inserido no parênquima aquífero predominante. No pecíolo de I. pes-caprae e I. imperati identifica-se um conjunto de feixes bicolaterais arranjados em semicírculo, envolvido por uma endoderme amilífera. Em C. rosea (Fig. 5 h) e $S$. tomentosa encontra-se um único feixe vascular colateral em formato de meia lua, mergulhado no amplo córtex parenquimático aclorofilado; fibras não lignificadas envolvem o sistema condutor. Na bainha foliar de $M$. maritima e $S$. virginicus os tecidos condutores estão envolvidas por fibras de paredes delgadas e fracamente lignificadas, que constituem extensões vasculares proeminentes (Fig. 5g).

\section{Discussão}

A análise qualitativa realizada mostrou que as halófitas e psamófilas reptantes estudadas exibem, de modo geral, diversos caracteres anatômicos potencialmente adaptativos à sobrevivência em ambientes salinos. Foram verificadas camadas cuticulares relativamente espessas; tricomas tectores e glandulares; estômatos, em geral, protegidos; abundante tecido de reserva de água; cristais e compostos fenólicos. As plantas que ocorrem em formações abertas, tais como a restinga, localizadas nas porções periféricas da Mata Atlântica, estão sujeitas a condições ambientais mais extremas e adversas do que as de áreas mais protegidas (Scarano 2002). Desse modo, os resultados aqui obtidos, corroboram com o proposto para as condições abióticas litorâneas, sob as quais são encontradas as espécies selecionadas.
Nas folhas de locais secos a parede celular epidérmica, a camada cuticular e de cêras que as recobrem tendem a ser espessadas quando comparadas com as de plantas crescidas em ambientes úmidos e sombreados (Pyykkö 1966). A cutícula, estrutura hidrofóbica responsável pela redução da transpiração cuticular e da lixiviação de nutrientes, também protege a folha contra a ação dos ventos e invasão de fungos (Grubb 1977; Juniper \& Jeffree 1983; Turner 1994). Os resultados obtidos indicam a importância protetora dessa camada, espessa na maior parte das espécies, confirmam as hipóteses de Kozlwoski (1997), segundo o qual as paredes das células epidérmicas e a cutícula das folhas de plantas que crescem em áreas salinizadas são mais espessas.

Os tricomas tectores, além de atuarem na reflexão da luminosidade, podem alterar as características espectrais da folha, diminuindo a absorbância e evitando a fotoinibição (Johnson 1975; Lin \& Ehleringer 1983). Em algumas espécies podem também diminuir a absorção de ondas curtas, evitando elevação de temperatura, além de reduzirem a perda de água (Press 1999; Gutschick 1999), efeitos que poderiam ser considerados importantes para as plantas de ambientes intensamente iluminadas, e sujeitos ao déficit hídrico, tais como as restingas. Por outro lado, os tricomas glandulares são considerados efetivo recurso na dissuasão dos insetos herbívoros em função dos componentes químicos, às vezes tóxicos, produzidos e volatilizados na superfície das plantas (Gonzáles et al. 2008; Wagner 1991; Johnson 1975).

Entre as halófitas que não evitam a entrada de sais pelas raízes, destacam-se os tricomas especializados na eliminação de sal, descritos para diversas famílias de angiospermas que ocupam ambientes salinos (Fahn 1979). Em Reaumuria hirtella Jaub. $\&$ Spach. (Tamaricaceae), que ocorre em ambientes secos e salinizados do Egito, a secreção da maior parte do sódio absorvido pelas raízes, se dá durante o período noturno, sob condições de alta umidade atmosférica, 


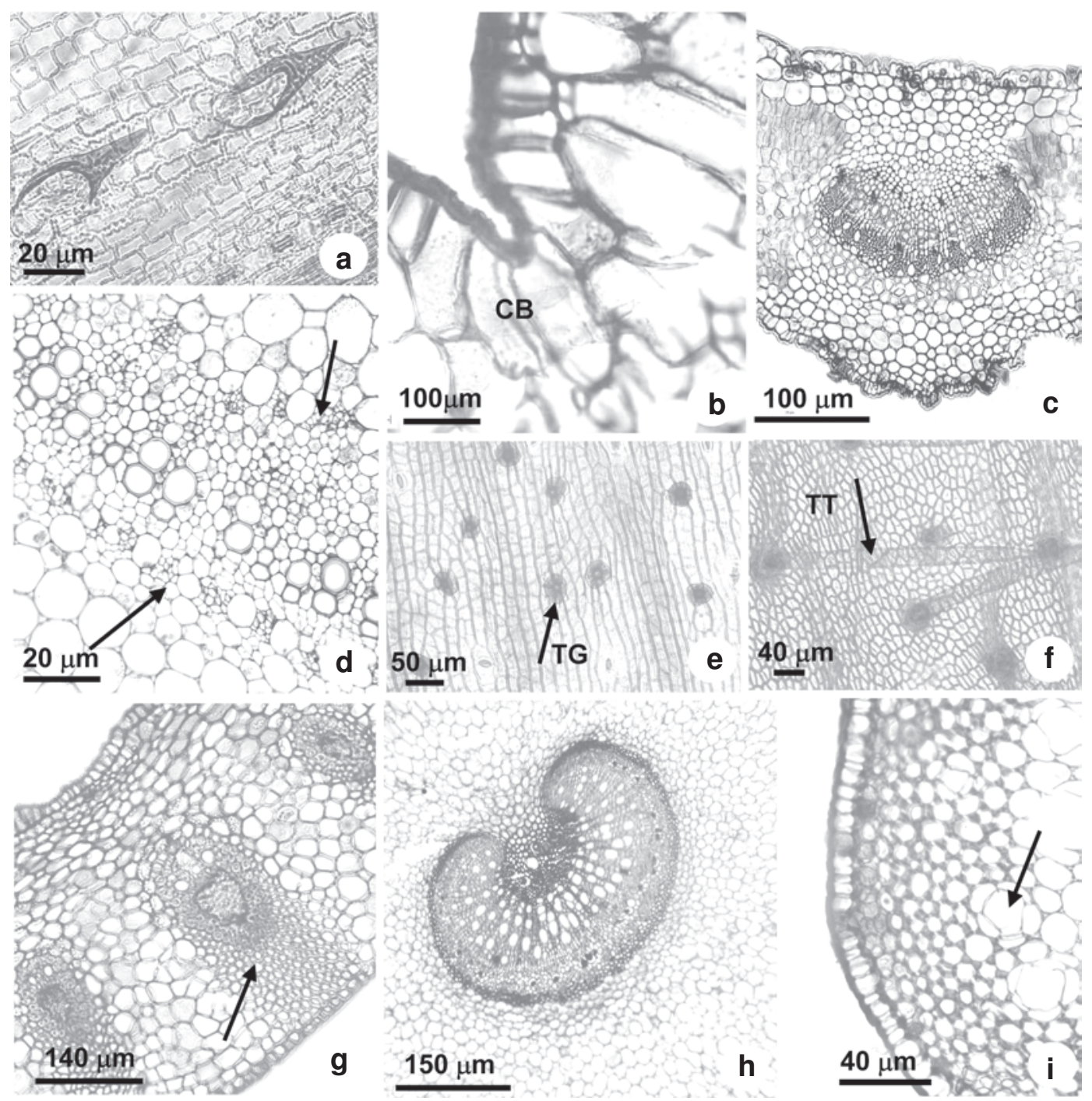

Figura 5 - Detalhes da epiderme no bordo e pecíolo/peciólulo e bainha em vista frontal e em secções transversais - a. lâmina foliar de Miegia maritima na região do bordo, evidenciando presença de tricomas tectores; b. lâmina foliar $M$. maritima, células buliformes na região da nervura principal (CB); c. Sophora tomentosa, região da nervura principal e amplo córtex aclorofilado; d. Ipomoea pes-caprae, região da nervura principal destacando floema externo e interno ao xilema; e. epiderme foliar do pecíolo de Ipomoea pes-caprae destacando organização das células e presença de tricomas glandulares (TG); f. epiderme do peciólulo de Canavalia rosea destacando tricomas tectores (TT); g. bainha foliar de Sporobolus virginicus, organização do mesofilo e sistema vascular com extensão de bainha fibrosa (seta); h. seção transversal do peciólulo de Canavalia rosea destacando amplo córtex e organização do sistema vascular; i. pecíolo de I. imperati, canais secretores de látex contornados por células secretoras de paredes delgadas (seta).

Figure 5 - Leaf margin, petiole/petiolule and leaf sheath in cross section - a. leaf margin of Miegia maritima, non-glandular trichomes; b. leaf lamina of M. maritima: bulliform cells at midrib (CB); c. Sophora tomentosa, midrib and wide cortex with chlorenchymatic cells; d. Ipomoea pes-caprae, midrib with phloem occuring inside and ouside xylem tissue; e. petiole epidermis of Ipomoea pes-caprae, cell organization and glandular trichomes (TG); f. petiolule epidermis of Canavalia rosea, tector trichomes (TT); g. leaf margin of Sporobolus virginicus, mesophyll structure and vascular bundles with extension composed by fibers (arrow); h. cross section of the petiolule of Canavalia rosea, wide cortex and vascular system; i. petiole of I. imperati, laticifer channels surrounded by secretory cells with thin walls (arrows). 
Tabela 3 - Características do mesofilo, pecíolo, peciólulo ou bainha de halófitas e psamófilas reptantes da Restinga de Ipitangas, Saquarema, Rio de Janeiro.

Table 3 - Anatomical characteristics from the mesophyll, petiole, petiolule or sheath from halophytes and reptants psamophytes from the sandy coastal plains (restinga) of Ipitangas, municipality of Saquarema, Rio de Janeiro.

\begin{tabular}{|c|c|c|c|c|c|c|c|}
\hline Caráter/espécie & B. portulacoides & C. rosea & I.pes-caprae & I. imperati & M. maritima & S. tomentosa & S. virginicus \\
\hline Estrutura da folha & $\begin{array}{l}\text { Kranz, bainha } \\
\text { não lignificada }\end{array}$ & isolateral & isolateral & isolateral & $\begin{array}{l}\text { Kranz, bainha } \\
\text { lignificada }\end{array}$ & dorsiventral & $\begin{array}{l}\text { Kranz, bainha } \\
\text { não lignificada }\end{array}$ \\
\hline Hipoderme aquífera & ausente & ausente & ausente & ausente & ausente & presente & ausente \\
\hline $\begin{array}{l}\text { Localização do } \\
\text { tecido aquífero }\end{array}$ & $\begin{array}{l}\text { face inferior } \\
\text { da folha } \\
\text { bordo }\end{array}$ & $\begin{array}{l}\text { junto aos feixes } \\
\text { vasculares } \\
\text { (extensões) } \\
\text { bordo } \\
\text { peciólulo }\end{array}$ & $\begin{array}{l}\text { meio da folha } \\
\text { em torno dos } \\
\text { feixes } \\
\text { vasculares } \\
\text { pecíolo }\end{array}$ & $\begin{array}{l}\text { meio da folha } \\
\text { em torno dos } \\
\text { feixes } \\
\text { vasculares } \\
\text { pecíolo }\end{array}$ & $\begin{array}{l}\text { fce superior } \\
\text { da folha } \\
\text { bainha foliar }\end{array}$ & $\begin{array}{l}\text { hipoderme } \\
\text { junto aos } \\
\text { feixes vasculares } \\
\text { (extensões) } \\
\text { peciólulo }\end{array}$ & Bainha foliar \\
\hline $\begin{array}{l}\text { Tipo de inclusão } \\
\text { cristalífera }\end{array}$ & drusas & $\begin{array}{l}\text { cristais } \\
\text { romboédricos }\end{array}$ & drusas & drusas & $\longrightarrow$ & $\begin{array}{l}\text { cristais } \\
\text { romboédricos }\end{array}$ & - \\
\hline $\begin{array}{l}\text { Extensão fibrosa } \\
\text { no feixe vascular }\end{array}$ & ausente & ausente & ausente & ausente & presente & presente & presente \\
\hline $\begin{array}{l}\text { Fibras lignificadas } \\
\text { no pecíolo, } \\
\text { peciólulo ou } \\
\text { bainha }\end{array}$ & ausente & ausente & ausente & ausente & presente & ausente & $\begin{array}{l}\text { presente } \\
\text { (fracamente } \\
\text { lignificada) }\end{array}$ \\
\hline
\end{tabular}


através de tricomas especializados (Ramadan 1998). Para espécies de Phillyrea L. (Oleaceae) do Mediterrâneo são descritos tricomas secretores de sais semelhantes aos encontrados em Avicennia L. (Acanthaceae), assim como para algumas gramíneas halófitas (Gucci et al. 1997; Marcum \& Pesarakli 2006). Com exceção dos hidatódios observados em C. rosea, I. pes-caprae e I. imperati, nas demais espécies do presente estudo não foram encontradas estruturas associadas à excreção de soluções hidrofílicas ou salinas, indicando que outros mecanismos estejam envolvidos no processo inibição da entrada de sais pelas raízes, acúmulo e eliminação desses materiais pelas folhas.

As células buliformes observadas em $S$. virginicus e M. maritima, maiores que as demais células epidérmicas, estão em acordo com o mencionado para outras Poaceae e Cyperaceae (Metcalfe 1971). Essas células estão relacionadas com enrolamento da folha em situações de estresse hídrico ou durante a expansão foliar a partir da gema (Fahn 1990). Tais células ainda podem ter potencial função de reserva de água, assim como as células epidérmicas comuns que, pelo menos em parte das espécies aqui estudadas, apresentaram-se volumosas.

Idioblastos com cristais foram observados na epiderme de algumas das espécies analisadas. Em S. virginicus e M. maritima foram detectadas inclusões de sílica; em $C$. rosea foram encontrados cristais retangulares de oxalato de cálcio e para $S$. tomentosa não foi reconhecida a composição química das estruturas cristalíferas com os testes histoquímicos realizados. Cristais de sílica em células epidérmicas são interpretados como um atributo marcante das Cyperaceae e Poaceae (Metcalfe 1971), sendo mencionada para outras espécies brasileiras dessas famílias (Vieira et al. 2002; Silva \& Alquini 2003). De modo geral, os depósitos cristalíferos nas células da epiderme são considerados importantes na defesa vegetal, pois tornam as folhas mais rígidas e resistentes contra a ação do vento e chuvas (Haberlandt 1928; Mc Naughton \& Tarrants 1983). Para Fahn \& Cuttler (1992), os cristais representam um importante caráter xeromorfo, atuando na proteção contra a herbivoria. Tais hipóteses poderiam ser propostas para as plantas aqui analisadas, tendo em vista as condições ambientais adversas a que estão submetidas.

As folhas dessas espécies exibiram diferentes padrões de localização dos estômatos (epiestomáticas, hipoestomáticas e anfiestomáticas). Distribuição estomática variada também foi citada para espécies lenhosas ou herbáceas da restinga (Vieira 1995; Arruda \& Gomes 1996; Mantuano et al. 2006). A maior parte das plantas terrestres tem estômatos localizados na face inferior da lâmina; esse padrão pode ser modificado nas folhas espessas, em geral anfiestomáticas (Smith et al. 1997), como verificado para algumas das espécies avaliadas, excetuandose aquelas nas quais as camadas do parênquima aquífero encontram-se em posição subepidérmica.

A estrutura foliar das halófitas e psamófilas analisadas variou entre dorsiventral, isobilateral e Kranz, de acordo com a espécie. O amplo desenvolvimento do parênquima paliçádico é frequente entre as espécies da restinga, já que as folhas recebem intensa luminosidade em uma ou ambas as faces da lâmina. O paliçádico atua direcionando os raios luminosos para as camadas mais internas do mesofilo, atenuando a absorção da luz vermelha e azul, reduzindo os danos fotoinibitórios ao parênquima esponjoso (Vogelmann \& Martin 1993; Sun et al. 1996).

A anatomia Kranz, caracterizada pela presença de células do clorênquima organizadas radialmente à endoderme clorofilada, pode ser encontrada em pelo menos 14 famílias de angiospermas (Majerowicz 2004). Nesse estudo foi reconhecida em $B$. portulacoides e $S$. virginicus. Esse padrão pode ser observado em plantas com assimilação do tipo $\mathrm{C}_{4}$, que crescem sob condições limitantes para a aquisição de carbono impostas pela alta temperatura, seca e condições salinas (Vosnesenskaia et al. 
2001). Nas plantas com assimilação do tipo $\mathrm{C}_{4}$, o espessamento da parede das células da bainha vascular é considerado uma importante característica estrutural que previne o retorno do $\mathrm{CO}_{2}$ às células do mesofilo, resultando em uma concentração até 20 vezes maior deste gás no interior da folha, em relação à atmosfera (Press 1999).

A suculência é uma das mais notáveis características das halófitas. Espécies com folhas suculentas são comumente encontradas em ambientes com solos salinos (Fahn \& Cuttler 1992). De acordo com Dickison (2000), halófitas apresentam folhas suculentas com células aclorofiladas e capazes de acumular sal, mobilizando-o das raízes. A suculência aumenta de acordo com a salinidade do solo (Serag 1999) e é o efeito típico manifestado por plantas submetidas à ação do cloreto de sódio (Larcher 1995). Nas espécies não tolerantes, a salinidade causa injúrias às membranas celulares, resultando na perda de solutos, além de causar o colapso das células do mesofilo, fragmentação da cutícula, desintegração do citoplasma, cloroplastos e núcleo, levando à redução no crescimento e queda na produtividade (Kozlowiski 1997; Gao et al. 2007). A maior parte das halófitas tolera altas concentrações de sal nos tecidos através de ajustes osmóticos. Os sais absorvidos são sequestrados nos vacúolos, reduzindo a exposição a que o citoplasma e os cloroplastos estão submetidos (Kozlowski 1997). No presente estudo, tecidos aquíferos foram verificados em diferentes graus de desenvolvimento e localização na folha de todos os táxons analisados - epiderme, hipoderme, envolvendo o sistema vascular, no bordo, no pecíolo, peciólulo ou bainhas foliares, corroborando as afirmações anteriores sobre o papel desse tecido para o grupo de plantas analisado.

No sistema vascular, as extensões dos feixes representam uma barreira à difusão dos gases. Quando a abertura estomática ocorre de forma desigual na epiderme, são gerados compartimentos onde a assimilação se dá de forma independente (Evans \& von Caemmerer 1996). Estas extensões podem ainda estar relacionadas à sustentação das folhas ou ao transporte de água e outras substâncias até as camadas subepidérmicas e epidérmicas, como verificado em plantas de deserto (Wylie 1943; Fahn \& Cuttler 1992). Para as plantas aqui analisadas, as extensões dos feixes vasculares também poderiam atuar na reserva de água para as folhas, tendo em vista serem constituídos por células volumosas aclorofiladas.

Os idioblastos contendo drusas de oxalato de cálcio, gorduras ou fenóis estão relacionados à defesa química da planta. Idioblastos com fenóis foram encontrados em células parenquimáticas da bainha e do mesofilo de M. maritima. Para algumas plantas crescidas sob condições salinas, o acúmulo de substâncias orgânicas no citoplasma ou vacúolo é uma estratégia que faz parte dos mecanismos de defesa relacionados com o ajustamento osmótico, a estabilidade de proteínas e membranas celulares, além da proteção contra os radicais livres de $\mathrm{O}_{2}$, sintetizados em resposta ao estresse salino e hídrico (Costa et al. 2003).

Foi observado maior desenvolvimento de fibras, associadas ou não ao sistema vascular, em $S$. virginicus e $M$. maritima. Por outro lado, essas espécies não apresentam folhas suculentas, indicando que a esclerofilia não é a uma estratégia adotada por todas as halófitas. Estes resultados confirmam os dados de Boeger \& Gluzezak (2006) que observaram baixos valores de peso seco nas halófitas, nas quais o tecido predominante para este grupo de plantas é o de reserva de água.

Nas plantas analisadas identificou-se fraca lignificação ou mesmo ausência de fibras lignificadas nas regiões da bainha, pecíolo e nervura central, sendo a sustentação conferida por camadas de colênquima ou fibras de paredes primárias e espessadas. Em alguns estudos tem sido observado que a mudança no ângulo de inclinação de folhas crescidas sob 
irradiâncias potencialmente danosas é um recurso protetor utilizados pelas plantas (Vogelmann et al. 1996; Gamon \& Pearcy 1989; Klich 2000). Os resultados aqui obtidos corroboram as propostas de Boeger \& Gluzezak (2006), pelo menos para C. rosea e I. pes-caprae, cujas folhas formam acentuados ângulos de inclinação com o solo durante alguns períodos do dia. É possível que nas plantas deste estudo a constituição dos tecidos, especialmente a ausência de lignificação nas paredes das fibras do pecíolo/peciólulo e na região da nervura central possam permitir os movimentos da lâmina. Tal fato não só evitaria a fotoinibição como também os danos causados pelo vento.

Esse estudo revelou alguns caracteres frequentemente observados em espécies submetidas a diferentes tipos de pressões ambientais. Não foram detectados os tricomas tipicamente associados às halófitas, responsáveis pela eliminação de sais, embora algumas das plantas estudadas sejam frequentemente submetidas à lavagem pela água do mar. Também não ficaram evidentes características que possam ser empregadas na separação espacial das espécies aqui investigadas em relação às comunidades que ocupam. Desse modo, as halófitas e psamófilas estudadas compartilham muitos caracteres de resistência ao ambiente da restinga. Algumas características observadas podem ser consideradas xeromorfas e relacionadas à economia de água, além de favorecerem a permanência dessas plantas no ambiente costeiro. Os atributos encontrados, possivelmente, conferem às folhas aumento da longevidade $\mathrm{e}$ maior eficiência na conservação dos nutrientes adquiridos (Mooney \& Gulmon 1982; Witkowiski \& Lamont 1991; Turner 1994).

\section{Agradecimentos}

Ao Conselho Nacional de Desenvolvimento Científico e Tecnológico $(\mathrm{CNPq})$ pela bolsa de Iniciação Científica (PIBIC-UNIRIO) concedida à N. S. F. Viglio. Aos revisores anônimos pelas valiosas sugestões apresentadas.

\section{REFERÊNCIAS BIBLIOGRÁFICAS}

Araujo, D. S. D. 2000. Análise florística e fitogeográfica das restingas do estado do Rio de Janeiro. Rio de Janeiro. Tese de Doutorado. Universidade Federal do Rio de Janeiro, Rio de Janeiro, 169 p.

Araujo, D. S. D.; Sá, C. F. C.; FontellaPereira, J.; Garcia, D. S.; Ferreira, M. V.; Paixão, R. J.; Schneider, S. M. \& Fonseca-Kruel, V. S. 2009. Área de Proteção Ambiental de Massambaba, Rio de Janeiro: caracterização fitofisionômica e florística. Rodriguésia 60 (1): 067-096.

Araujo. D. S. D. \& Henriques, R. P. B. 1984. Análise florística das restingas do estado do Rio de Janeiro. In: Lacerda, L. D.; Araujo, D. S. D.; Cerqueira, R. \& Turq, B. (eds.). Restingas: origem, estrutura, processos. EDUFF, Niterói. Pp. 159-166.

Arruda, R. C. O. \& Gomes, D. M. S. 1996. Anatomia foliar de Mitracarpus frigidus (Willd.) K. Schum. var. salzmanianus (DC.) K. Schum. e Mitracarpus lhotzkianus Cham. (Rubiaceae). Bradea 50(6): 431-444.

Boeger, M. R. T. \& Gluzezak, R. M. 2006. Adaptações estruturais de sete espécies de plantas para as condições ambientais da área de dunas de Santa Catarina, Brasil. Iheringia, Série Botânica 61(1-2): 73-82.

Costa, P. H. A.; Silva, J. V.; Bezerra, M. A.; Enéas Filho, J.; Prisco, J. T. \& Gomes Filho, E. 2003. Crescimento e níveis de solutos orgânicos e inorgânicos em cultivares de Vigna unguiculata submetidos à salinidade. Revista Brasileira de Botânica 26(3): 289-297.

Dickison, W. C. 2000. Integrative plant anatomy. Harcout Academic Press, San Diego, 533p.

Evans, J. R \& von Caemmerer, S. 1996. Carbon dioxide diffusion inside leaves. Plant Physiology 110: 339-346.

Fahn, A. \& Cuttler, D. F. 1992. Xerophytes. Ed. Gerbruder Borntraeger, Berlin, 176p. 
Fahn, A. 1979. Secretory tissues in plants. Academic Press, London, 302p.

Fahn, A. 1990. Plant anatomy. 4ed. Pergamon Press, Oxford, 588p.

Flowers, T. J. \& Flowers, S. A. 2005. Why does salinity pose such a difficult problem for plant breeders? Agriculture Water Management 78(1): 15-24.

Foster, A. S. 1950. Practical plant anatomy. 2ed. D. van Nostrand Inc, New York, 228p.

Gamon, J. A. \& Pearcy, R. W. 1989. Leaf movement, stress avoidance and photosynthesis in Vitis californica. Oecologia 79: 475-481.

Gao, Ji-P.; Chao, Dai-Y. \& Lin, Hong-X. 2007. Understanding abiotic stress tolerance mechanisms: recent studies on stress response in rice. Jounal of Integrative Plant Biology 49: 742-750.

Gonzáles, W. L.; Negritro, M. A.; Suárez, L. H. \& Gianoli, E. 2008. Induction of glandular and non-glandular trichomes by damage in leaves of Madia sativa under contrasting water regimes. Acta Oecologica 33:128-132.

Grubb. 1977. The maintence of species richness in plant communities and the importance of the regeneration niche. Biol. Rev. 52:107-145.

Gucci, B.; Aronne, G.; Lombardini, L. \& Tattini, M. 1997. Salinity tolerance in Phillyrea species. New Phytologist 135: 227-234.

Gutschick, V. P. 1999. Biotic and abiotic consequences of differences in leaf structure. New Phytologist 143(1): 3-18.

Haberlandt, G. 1928. Physiological plant anatomy. Macmillan, London, 777p.

Hay, J. D. \& Lacerda, L. D. 1984. Ciclagem de nutrientes do ecossistema restinga. In: Lacerda, L. D; Araujo, D. S. D.; Cerqueira, R. \& Turq, B. (eds.). Restingas: origem, estrutura e processos. CEUFF. Pp. 459-475.

Jensen, W. A. 1962. Botanical histochemistry: principles and pratice. W. H. Freeman, San Francisco, 408p.
Johansen, D. A. 1940. Plant microtechnique. McGrow-Hill, New York, 523p.

Johnson, H. B. 1975. Plant pubescence as an ecological perspective. Botanical Review 41(3): 234-258.

Juniper, B. E. \& Jeffree, C. 1983. Plant surfaces. Edward Arnold Pub, London, 93p.

Klich, M. G. 2000. Leaf variations in Elaeagnus angustifolia related to environmental heterogeneity. Environmental and Experimental Botany 44: 171-183.

Koyro, H. W. 2006. Effect of saliniy on growth, photosynthesis, water relations and solute composition of the potencial cash crop halophyte Plantago coronopus L. Environmental and Experimental Botany 56: 136-146.

Kozlowski, T. T. 1997. Responses of woody plants to flooding and salinity. Tree Physiology, Monography 1: 1-29.

Kraus, J. E. \& Arduin, M. 1997. Manual básico de métodos em morfologia vegetal. EDUR, Seropédica, 198p.

Larcher, W. 1995. Physiological plant ecology. 3ed. Springer, Berlin, 506p.

Lin, Z. F \& Ehleringer, J. 1983. Epidermis effects on spectral properties of leaves of four herbaceous species. Physiologia Plantarum 59: 91-94.

Majerowicz, N. 2004. Fotossíntese. In: Kerbauy, G. B. (ed.). Fisiologia vegetal. Guanabara Koogan, Rio de Janeiro. Pp. 114-178.

Mantovani, A. \& Iglesias, R. R. 2001. Bromélias terrestres na restinga da Barra de Maricá, RJ: influência sobre o microclima, o solo e a estocagem de nutrientes em ambiente de borda de moitas. Leandra 16: 17-36.

Mantuano, D. G.; Barros, C. F. \& Scarano, F. R. 2006. Leaf anatomy variation with and between three "restinga" populations of Erythroxylum ovalifolium Peyr. (Erythroxylaceae) in Southeastern Brazil. Revista Brasileira de Botânica 29(2): 209-215.

Marcum, K. B. \& Pesarakli, M. 2006. Salinity tolerance and salt gland excretion 
efficiency of Bermuda grass turf cultivars. Crop Science 48: 2571-2574.

Mc Naughton, S. J. \& Tarrants, J. L. 1983. Grass leaf silification: natural selection for an inducible defense against herbivores. Proceedings of Natural Sciences 80: 790-791.

Metcalfe, C.R. 1971. Anatomy of monocotyledons. Cyperaceae. Clarendon Press, Oxford, 597p.

Mooney, H. A. \& Gulmon, S. L. 1982. Constraints on leaf structure and function in reference to herbivory. BioScience 32(3): 198-206.

Pammenter. N. W. 1984. Ecological and physiological aspects of plant communities of the sand dunes of the east coast of Southern Africa. In: Lacerda, L. D.; Araujo, D. S. D.; Cerqueira, R. \& Turq, B. (eds.). Restingas: origem, estrutura e processos. CEUFF. Pp. 425-440.

Pfadenhauer, J. 1978. Contribuição ao conhecimento da vegetação e suas condições de crescimento das dunas costeiras do Rio Grande do Sul. Revista Brasileira de Botânica (38): 827-836.

Press, M. C. 1999. The functional significance of leaf structure: a search for generalizations. New Phytologist 143:213-219.

Pyykkö, M. 1966. The leaf anatomy of East Patagonian xerophytic plants. Annales Botanici Fennice 3(4): 453-622.

Ramadan, R. 1998 Ecophysiology of salt excretions in tha xero-halophyte Reaumuria hirtella. New Phytologist 139: 273-281.

Reinert, F.; Roberts, A.; Wilson, J. M.; Ribas, L.A.; Cardinot, G. \& Griffiths, H. 1997. Gradations in nutrient composition and photosynthetic pathways across the restinga vegetation of Brasil. Botanica Acta (110):135-142.

Sá, C. F. C. 1993. A vegetação da Restinga de Ipitangas. Reserva Ecológica Estadual de Jacarepiá, Saquarema, RJ: fisionomia e listagem de Angiospermas. Arquivos do Jardim Botânico do Rio de Janeiro 81: 87-102.

Sá, C. F. C. \& Araujo, D. S. D. 2009. Estrutura e florística de uma floresta de restinga em Ipitangas, Saquarema, Rio de Janeiro, Brasil. Rodriguésia 60 (1): 147-170.

Sass, J. E. 1951. Botanical microtechinique. 2ed. Ames, The Iwoa State College Press, Iwoa, 391p.

Scarano, F. R. 2002. Structure, function and floristic relationships of plant community in stressful habitats marginal to the Brazilian Atlantic Rainforest. Annals of Botany 90: 517-524.

Serag, M. S. 1999. Ecology of four succulent halophytes in the Mediterranean coast of Damietta, Egypt. Estuarine coastal and Shelf Science 49: 29-36.

Silva, L. M. \& Alquini, Y. 2003. Anatomia comparativa de folhas e caules de Axonopus scoparius (Flugge) Kuhlm. e Axonopus fissifolius (Raddi) Kuhlm. (Poaceae). Revista Brasileira de Botânica 26(2): 185-192.

Smith, W. K.; Vogelmann, T. C.; Delucia, E. H.; Bell, D. T. \& Shepherd, K. A. 1997. Leaf form and photosynthesis. Bioscence 46(1): 785-793.

Strasburger, E. 1924. Handbook of practical botany. 8ed. Sonneschein \& Co., London, 533p.

Street, H. E. \& Öpik, H. 1984. The physiology of flowering plants. 3ed. Contemporary Biology, London, 279p.

Suguio, K. \& Tessler. M. G. 1984. Planície de cordões litorâneos quaternários do Brasil: origem e nomenclatura. In: Lacerda, L. D.; Araujo, D. S. D.; Cerqueira, R. \& Turq, B. (eds.). Restingas, origem, estrutura, processos. CEUFF. Pp. 15-25.

Sun, J. N.; Nishio, J. N. \& Vogelmann, T. C. 1996. Hight-light on effects on $\mathrm{CO}_{2}$ fixation gradients across leaves. Plant, Cell and Environment 19: 1261-1271.

Turner, I. M. 1994. Sclerophylly: primarily protective? Functional Ecology 8: 669675. 
Vieira, R. C. 1995. Anatomia da folha de Bauhinia radiata Vell. em diferentes ambientes. Brazilian Archives of Biology and Technology 38(1): 63-107.

Vieira, R. C.; Gomes, D. M. S.; Arruda, R. C. O. $\&$ Sarahyba, S. 2002. Leaf anatomy of three bamboo herbaceous species. Revista Brasileira de Biologia 62(4b): 907-922.

Vogelmann, T. C.; Bornman, J. F. \& Yates, D. J. 1996. Focusing of light by leaf epidermal cells. Physiologia Plantarum 98: 43-56.

Vogelmann, T. C. \& Martin, G. 1993. The funcional significance of palisade tissue: penetration of directional versus diffuse light. Plant, Cell and Environment 16: 65-72.
Vosnesenskaia, E.; Franceschi, V. R.; Kiirats, O.; Freitag, H. \& Edwards, G. E. 2001. Kranz anatomy is not essencial for terrestrial $\mathrm{C}_{4}$ plant photosynthesis. Nature 414: 543-546.

Wagner, G. J. 1991. Secreting glandular trichomes: more than just hairs. Plant Physiology 96: 675-679.

Witkowoski, E. T. F. \& Lamont, B. B. 1991. Leaf specific mass confounds leaf density and thickness. Oecologia 88: 486-493.

Wylie, R. B. 1943. The role of the epidermis in foliar organization and its relations to the minor venation. American Journal of Botany 30:272-280. 